\title{
FATAL DELIBERATE SELF HARM IN MANIPAL, INDIA: AUTOPSY STUDY
}

\author{
Shetty $\mathbf{C K}^{1}$, Palimar $\mathbf{V}^{2}$, Bhagavath $\mathbf{P}^{2}$, Kumar $\mathbf{G P}^{2}$ \\ ${ }^{1}$ Medical Lecturer, Department of Forensic Medicine, Faculty of Medicine and Health Sciences, \\ University Sultan Zainal Abidin, Kampus Kota, Jalan sultan mahmud, Kuala Terengganu, 21300 \\ Terengganu, Malaysia. \\ ${ }^{2}$ Department of Forensic Medicine and Toxicology, Kasturba Medical College, \\ Manipal University, Manipal.
}

\begin{abstract}
Fatal deliberate self harm (FDSH) or Suicide is a devastating act causing a great deal of suffering to survivors, relatives, friends and other people near to the victim of suicide. It is also a public health problem causing loss of life years, particularly in young people. In most countries suicide is condemned for cultural or religious reasons and surrounded by taboo (WHO 2002).
\end{abstract}

The present study sample consisted of 656 cases of fatal deliberate self harm (FDSH) out of the 3571 total autopsy cases. The occurrence of FDSH was $18.37 \%$ of all the medico-legal autopsies conducted (3571 cases) during the study period (1992-2012). The present study shows that the people of all age groups were involved. The highest incidence was amongst the 21-30 years $(35.06 \%)$ followed by $31-40$ years $(19.35 \%)$. Male victims predominated .Of these 656 cases, $436(66.5 \%)$ were males and $220(33.5 \%)$ were females. Present study predicts marriage as being one of the important risk factors for suicide. 417 cases out of 656 cases $(57.3 \%)$ were married. Most of the victims belonged to the Hindu religion (86.4\%) followed by Christians ( $8.4 \%)$ and Muslims $(3.7 \%)$. When we look at the presence of any past illness, 174 cases (26.5\%) were having some form of chronic physical and mental disorders at the time of committing suicides. Although seasonal variation is not much, however the present study reveals highest number of cases in summer season $(36.1 \%)$, followed by the winter, the rainy season. Despair with life due to financial restraints and family and marital disharmony constituting 79 $\%$ of the total cases was the most common motive for FDSH. $74.4 \%$ of the total victims in the present study used chemicals for terminating their lives and only $26.8 \%$ of the study group used physical methods for committing FDSH. Amongst those who opted for physical methods, hanging was the most common (15.6\%) followed by burns $(7.1 \%)$. Among the poisoning cases, organ phosphorus poisoning $(51 \%)$ was the most commonly used method for suicide

\section{INTRODUCTION}

Suicide (self inflicted death) is a complex phenomenon associated with psychological, biological and social factors involving by and large every corner of the world. It is distinctively a human affair and continues to be a major public health issue. It has always attracted the attention of not only the medical fraternity but also of the philosophers and theologians. ${ }^{1,2}$

According to Durham, the French biologist, suicide is "death resulting directly or indirectly from a positive or negative act of the victim himself, which he knows will produce this result". Suicide from an existential point of view reflects a behavior that seeks and finds the solution to an existential problem by making an attempt on life of the subject. Suicide is applicable to all acts terminating fatally. ${ }^{1,2,3 .}$

A 2006 report by the World Health Organization (WHO) states that nearly a million people take their own lives every year, more than those murdered or killed in war. Suicide rates are highest in Europe's Baltic states, where around 40 people per 100,000 die by suicide each year, second in line is in the Sub-Saharan Africa where 32 people per 100,000 die by suicide each 
year. The lowest rates are found mainly in Latin America and a few countries. In most countries the incidence of suicides is higher than that in Asia, So also in India the National crime research Bureau (NCRB), 2010, in their annual report on Incidence and Rate of Suicides during the Decade (2000-2010) have reported that, more than one lakh persons $(1,34,599)$ in the country lost their lives by committing suicide during the year 2010. This indicates an increase of $5.9 \%$ over the previous year's figure (1, 27,151).

The number of suicides in the country during the decade (2000-2010) has recorded an increase of $23.9 \%$ (from 1, 08,593 in 2000 to 1 , 34,599 in 2009). The increase in incidence of suicides was reported each year during the decade except in 2001. The population has increased by $18.3 \%$ during the decade but the rate of suicides in 2010 was 11.4 which are greater than 10.8 recorded in 2000 . The rate of suicides has shown a declining trend since 2000 to 2003. An increasing trend is observed during 2006 to 2010. There were 369 suicide cases every day and 15 Suicides took place every hour, in spite of the fact that suicide is still considered a crime under section 309 Indian Penal Code. ${ }^{6}$

Considering these facts, and keeping in view the magnitude of this problem, an attempt has been made in the present study to make a complete and thorough analysis of deliberate self harm in terms of various epidemiological features, recent trends and to identify the risk factors associated with it

\section{MATERIALS AND METHOD}

Present study is both prospective (October 2010 - May 2012) and retrospective (January 1992 October 2010) over a span of 20 years (January 1992- May 2012). The department of Forensic Medicine in Kasturba Medical College, Manipal undertakes medico-legal autopsies of un-natural deaths occurring in its Jurisdiction of Manipal Police Station and also takes cases referred from the adjoining districts and states of southern India. In case of retrospective study relevant data regarding the suicide was gathered from the autopsy files maintained in the department of Forensic Medicine, Police inquest reports and Hospital case records (if available). In case of prospective study, along with the above mentioned data, information was obtained from close relatives of the victims present at the mortuary as regarding the motive of the act and other relevant questions.

The manner of death was constructed as suicide or otherwise based on the inquest reports of the investigating officer

\section{RESULTS AND OBSERVATIONS}

A Total 3571 cases were autopsied in the department of Forensic Medicine, Kasturba Medical College, Manipal, Karnataka during the period of 20years from January 1992 to May 2012, out of which 656 were cases of Fatal Deliberate Self Harm (FDSH) or Suicide constituting $18.37 \%$ of total cases as depicted in Table No. 01. 
Table 01: Total number of autopsies

\begin{tabular}{|c|c|c|c|}
\hline Year & $\begin{array}{c}\text { Total number } \\
\text { of autopsies }\end{array}$ & $\begin{array}{c}\text { Suicide } \\
\text { cases }\end{array}$ & $\begin{array}{c}\text { Percentage (\%) of } \\
\text { suicide cases }\end{array}$ \\
\hline 1992 & 35 & 5 & 14.2 \\
\hline 1993 & 157 & 18 & 11.46 \\
\hline 1994 & 174 & 30 & 17.24 \\
\hline 1995 & 154 & 34 & 22.0 \\
\hline 1996 & 181 & 38 & 20.99 \\
\hline 1997 & 174 & 39 & 22.41 \\
\hline 1998 & 154 & 36 & 23.37 \\
\hline 1999 & 161 & 43 & $\mathbf{2 6 . 7 0}$ \\
\hline 2000 & 163 & 35 & 21.47 \\
\hline 2001 & 199 & 43 & 21.60 \\
\hline 2002 & 158 & 34 & 21.51 \\
\hline 2003 & 113 & 19 & 16.81 \\
\hline 2004 & 129 & 20 & 15.50 \\
\hline 2005 & 141 & 21 & 14.89 \\
\hline 2006 & 154 & 16 & 10.38 \\
\hline 2007 & 151 & 25 & 16.55 \\
\hline 2008 & 196 & 30 & 15.30 \\
\hline 2009 & 233 & 32 & 13.73 \\
\hline 2010 & 301 & 54 & 17.94 \\
\hline 2011 & 308 & 57 & 18.50 \\
\hline 2012 (up to May) & 135 & 25 & 18.51 \\
\hline Total & $\mathbf{3 5 7 1}$ & $\mathbf{6 5 6}$ & 18.37 \\
\hline & & & \\
\hline & & & \\
\hline
\end{tabular}

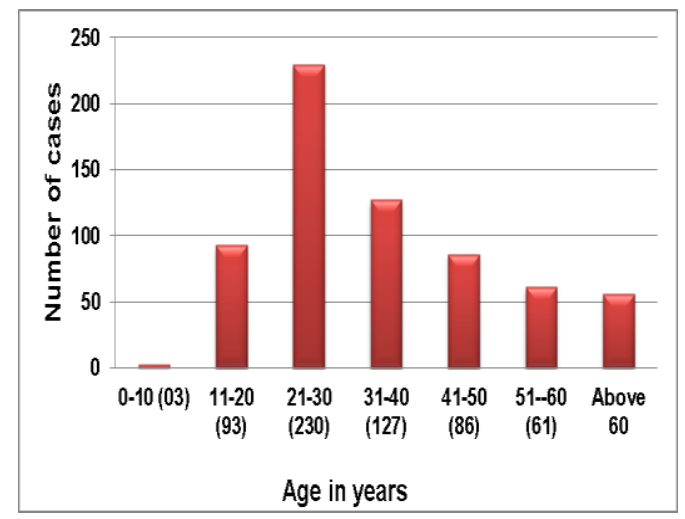

In our study, we observed that the highest incidence of suicide cases were found in the age group of 21-30 years which accounted for $35.06 \%$ of total cases, followed by the age group of 31 to 40 years. The least affected group was $0-10$ years who accounted for $0.45 \%$ of total cases, as depicted in the Fig. No. 01

Figure 01: Age of victims

aMale $(66.5 \%) \quad$ aFemale $(33.5 \%)$

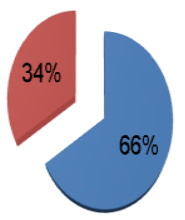

In our study, we observed that men outnumbered women, as depicted in the Fig. No. 02.

Figure 02: Gender distribution of the victims $(n=656)$ 


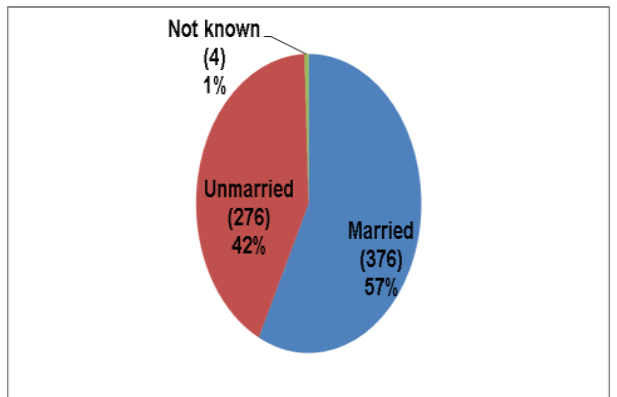

Our study showed that most of the decedents were married which accounted for $(57.3 \%)$ of all the cases of Fatal Deliberate Self Harm (FDSH), as depicted in Fig. No. 03.

Figure 03: Marital Status of the victims

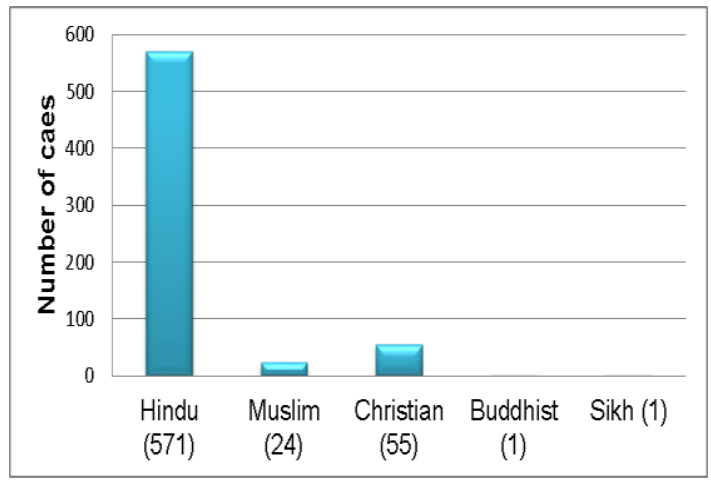

Most of the victims in this study were followers of the Hindu religion who accounted for $86.9 \%$ of all the cases of Fatal Deliberate Self Harm (FDSH), followed by the Christians $8.4 \%$, Muslims $3.7 \%$ and others $0.30 \%$ respectively, as depicted in the Fig. No. 04.

Figure 04: Religion of the victims.

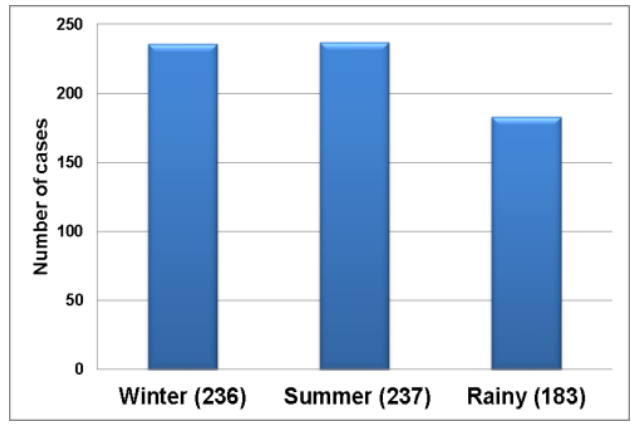

$\square$ Despair with Life $(79.0 \%) \quad$ a Physical illness $(14.0)$ $\checkmark$ Mental illness $(7.0 \%)$

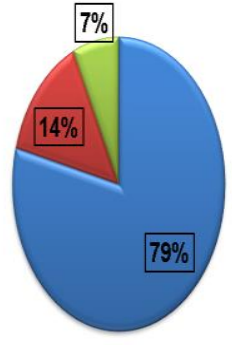

$36.1 \%$ of the victims committed Suicide during the Summer months, closely followed by the winter season which accounted for $36.0 \%$ of all the cases, rainy season witnessed the least number of fatalities $27.9 \%$. Fig. No. 05.

Figure 05: Seasonal variation in FDSH

Present study observed that despair with life was the main motive for FDSH in $79 \%$ of victims. Physical illness and Mental illness accounted for $14 \%$ and $7 \%$ of the total cases respectively in Fig. No. 06

Figure 06: Motive for FDSH. 


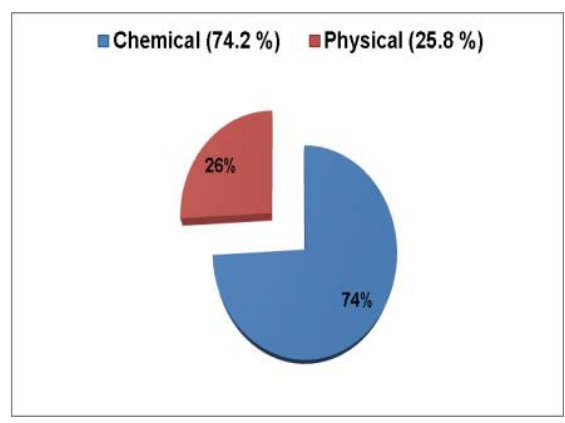

The majority of the decedents used chemical means to kill themselves and accounted for $74.2 \%$ of the total cases, Physical method was used by the remaining victims of FDSH as Depicted in Fig. No. 07.

Figure 07: Methods used for FDSH

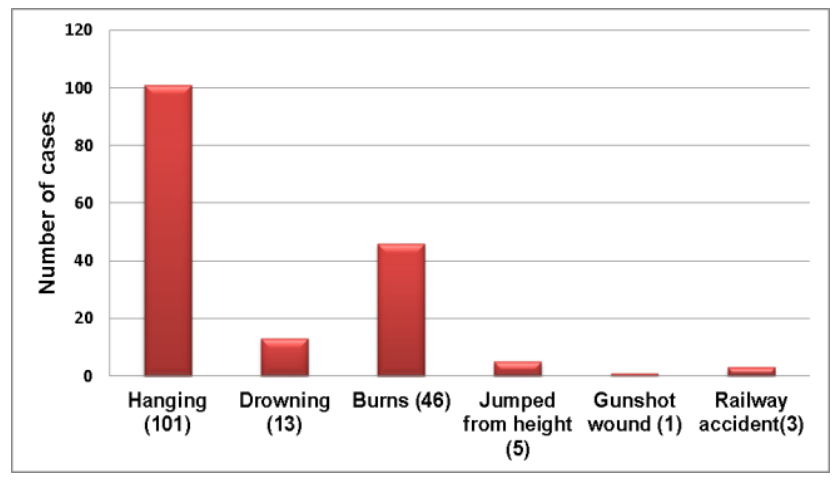

One fourth of the total population studied $(25.8 \%)$ opted for FDSH by physical means. Hanging contributing for the maximum number of cases $15.6 \%$, followed by burns $7.1 \%$, drowning $2.1 \%$, fall from height 0.8 $\%$, railway accident $0.5 \%$ and gunshot wound $0.2 \%$ respectively, as depicted in the Fig. No. 08.

Figure 08: Physical methods

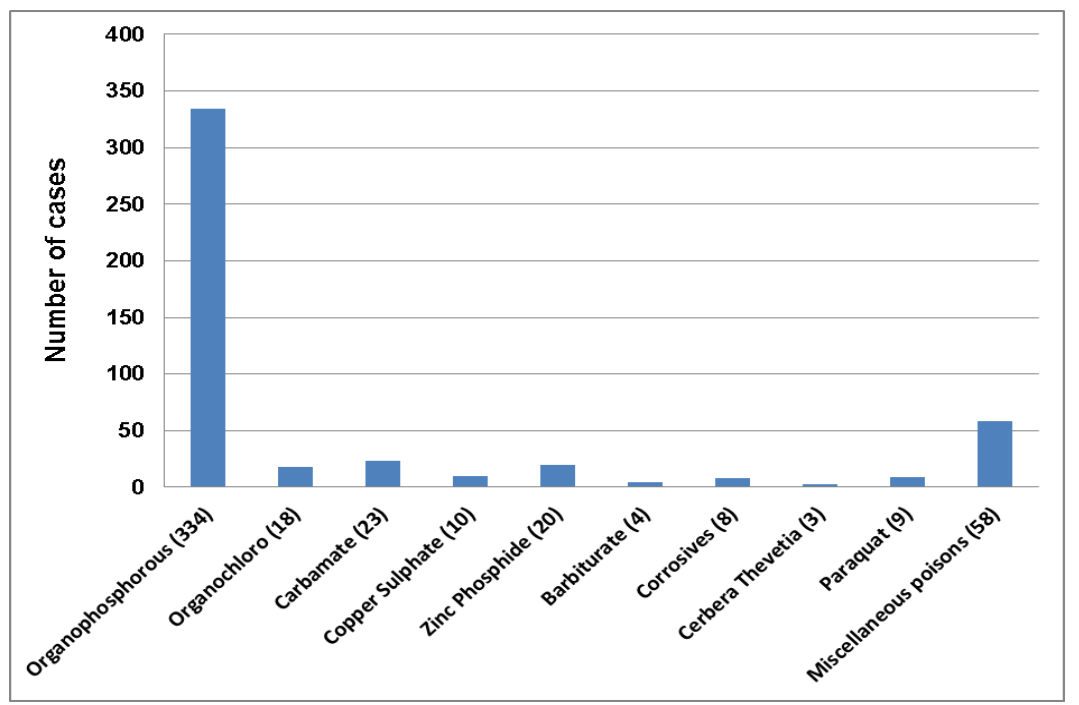

Analysis of the type of poison consumed for FDSH showed that $74 \%$ of the decedents consumed some chemical substance, the most common compound being Organ phosphorous insecticide $(50.9 \%)$, other poisons and their percentage as depicted in Fig. No.09

Figure 09: Chemical methods adopted

Present study showed that $20.7 \%$ of the decedents suffered from some kind of chronic physical illness disorders like Chronic Heart Disease (CHD), Diabetes, Renal failure, Bronchial asthma, Tuberculosis and Malignancy that included Carcinoma Breast, endometrial, stomach, lung and appendix. Mental illness included disorders ranging from Mental retardation, schizophrenia, bipolar disorders and depression which accounted for $3.6 \%$ of all the cases and a combination of both was observed in $2.2 \%$ of all the cases under study. There was no history of any illness in $73.5 \%$ of all the cases studied during the study period as depicted in Table No. 02 . 
Table 02: History of illness $(n=656)$

\begin{tabular}{|c|c|c|}
\hline History of illness & Number of cases & Percentage ( \% ) \\
\hline Mental illness & 23 & 3.6 \\
\hline $\begin{array}{c}\text { Chronic Physical Illness } \\
\text { including Malignancy }\end{array}$ & 137 & 20.7 \\
\hline Combination of both & 14 & 2.2 \\
\hline No history of illness & $\mathbf{4 8 2}$ & $\mathbf{7 3 . 5}$ \\
\hline Total & $\mathbf{6 5 6}$ & $\mathbf{1 0 0 . 0}$ \\
\hline
\end{tabular}

\section{DISCUSSION}

Fatal deliberate self harm (FDSH) or Suicide in general, across various civilizations, has been considered as a shameful act. Although it is widely encountered, the aetiology and various complexities involved are unfortunately illunderstood. A proper understanding of these aspects is a pre-requisite for suicide investigation. ${ }^{1}$

Suicide receives increasing attention worldwide, with many countries developing national strategies for prevention. Rates of suicide vary greatly between countries, with the greatest burdens in developing countries.

Trends of suicide vary widely according to time, region, age group, sex, and race. Despite mixed trends of increases or decreases in suicide rates around the world, suicide remains an important public-health problem. In an effort to understand and prevent suicide, researchers have investigated medical, psychosocial, cultural, and socio-economic risk factors associated with the environment as a promising line of research.

The present study sample consisted of 656 cases of fatal deliberate self harm (FDSH) out of the 3571 total autopsy cases. The occurrence of FDSH was $18.37 \%$ of all the medico-legal autopsies conducted (3571 cases) during the study period (1992-2012). It was $21.2 \%$ in another reported work done by Arun ${ }^{1}$

The present study shows that the people of all age groups were involved. The highest incidence was amongst the 21-30 years (35.06 $\%)$ followed by $31-40$ years $(19.35 \%)$. This observation was identical with the available literatures and studies done by Arun, ${ }^{1,2,3}$ B. D Gupta, ${ }^{5}$ National crime record bureau, ${ }^{6}$ Sachidananda.M, ${ }^{7} \quad$ Behera, ${ }^{8} \quad$ Lisa, ${ }^{18}$ B.R. Sharma,${ }^{24}$ Lalwani, ${ }^{54}$ Fernando, ${ }^{59}$ Gajalaxmi ${ }^{110}$. This is expected, as this age group comprises the majority of the population. Data from the World Health Organisation reports ${ }^{21}$ that adolescents and elderly individuals are at a higher risk of committing suicide. Young individuals are prone to being unable to cope with the turbulence occurring in their lives and so opt for deliberate self harm more often. ${ }^{1,5,6,7}$, $8,18,24,54,59,110$. But in contrast a study in Japan, ${ }^{7}$ Mexico ${ }^{1}$ and in South Carolina, USA, ${ }^{38}$ revealed that the most common age group of the victims was over 65 years.

Male victims predominated and this finding is consistent with the findings as observed by Arun, ${ }^{1,2,3}$ B. D Gupta, ${ }^{5}$ National crime record bureau, ${ }^{6} \quad$ Sachidananda.M, ${ }^{7}$ Behera, ${ }^{8}$ Danielle, ${ }^{11}$ Lisa B.R. ${ }^{18}$ S. Lalwani, ${ }^{54}$ Ravindra Fernando, ${ }^{59}$ and Vendhan ${ }^{110}$. Studies in other parts of the world also showed male predominance in suicides like in Cork City, in South Carolina, USA ${ }^{1,7,38}$ and in Geneva ${ }^{1,7}$. A study in England and Wales by Kelly and Bunting $\mathrm{J}^{65}$ suggests that there is an increase in the rate of suicide in both sexes but greater in males. The reasons being that the population of males are higher than that of female's worldwide. . $^{-3,5,6,7,11,18,54,59,110}$ However a literature search shows that, while men are known usually to commit suicide successfully, women have outnumbered men in non-fatal unsuccessful suicidal attempts. ${ }^{1,5,14,13,17 .}$ But in contrast to our observations in China, and in some studies done in India females commit

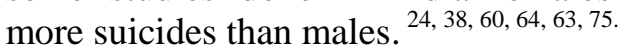


Present study predicts marriage as being one of the important risk factors for suicide. 417 cases out of 656 cases $(57.3 \%)$ were married which is almost similar to the findings observed in other parts of India (65\%). ${ }^{1,5,7}$ Married people (57.3 $\%)$ outnumbered their unmarried counterparts in Fatal deliberate self harm which is consistent with the study done by Arun, $1, \quad 2,3$ Sachidananda.M ${ }^{7}$. The reason for more suicides in married ones may be linked to the two most common causes of suicides (marital disharmony and financial burden). ${ }^{1} \quad$ But in Thailand similar incidences of suicides among both married and unmarried have been observed. ${ }^{7}$ However, western studies highlight that a high incidence of suicide has been observed among unmarried people. ${ }^{1}$ The present study shows that there are probably different factors relating to marital or family life that are operating in the Indian culture. The institutions of 'marriage' and 'family' are given the utmost respect and are followed with great fervour in the Indian tradition, whereas 'live-in' relationships without marriage are more popular in the western world. ${ }^{1}$

Most of the victims belonged to the Hindu religion $(86.4 \%)$ followed by Christians $(8.4 \%)$ and Muslims (3.7\%) consistent with the studies done by Arun. ${ }^{1,2}$ and Sachidananda.M. ${ }^{7}$ In India, a major part of the population follow Hinduism as their religion. ${ }^{1}$ Besides some isolated cases of Christians and Muslims, almost all the victims belonged to the Hindu religion. "Upanishads", the Holy scriptures of Hindus had condemned suicide and stated that 'he who takes his own life will enter the sunless areas covered by impenetrable darkness after death'. But the "Vedas" permitted suicide for religious reasons. It viewed that the best sacrifice, that could be made was one's own life. ${ }^{7}$

When we look at the presence of any past illness, 174 cases $(26.5 \%)$ were having some form of chronic physical and mental disorders at the time of committing suicides most commonly encountered diseases being hypertension, diabetes, malignancies of the lung, breast, stomach and mental illness including schizophrenia, bipolar disorders and depression which was similar to the studies done by A Behera, ${ }^{8}$ Danielle, ${ }^{11}$ Cavanagh J, ${ }^{49}$ Suleyman Goren. ${ }^{75}$ But in contrast to our findings some studies have stated that the main risk factor for both attempted and completed suicide is psychiatric disorder. ${ }^{22,16,46,48,49,50,75}$

Although seasonal variation is not much, however the present study reveals highest number of cases in summer season $(36.1 \%)$, followed by the winter, the rainy season witnessed the least number of fatalities which is consistent with the studies done by B. D Gupta, ${ }^{5}$ Sachidananda.M, ${ }^{7}$ Lisa. ${ }^{18}$ But contrast to the above finding was observed in Faisalabad, where a seasonal surge was observed in spring. ${ }^{7}$ In other studies conducted in India ${ }^{1}$ FDSH was seen more during the winter months and in other parts of the world, ${ }^{18,37,38}$ a spring peak for male and spring and autumn peaks for female suicides were found.

Despair with life due to financial restraints and family and marital disharmony constituting 79 $\%$ of the total cases was the most common motive for FDSH. Our findings are different from other reported works, which show a high correlation between mental illness and FDSH, ${ }^{22}$, $16,46,48,49,50,75$ but was similar to the studies done by Arun $^{1,2}{ }^{1, \text { Lisa }^{18}}$, B.R. Sharma ${ }^{24}$. In contrast to the statistics that mental illness is a predominant cause $(90 \%$ as per WHO statistics, $51 \%$ as in Singapore and $64.5 \%$ as in Wolver Hampton), we observed only $7.1 \%$ of all suicidal cases had mental illness. The reason may be reluctance by the people of this locality to attend a clinic for simple psychiatric complains consistent with finding of Sachidananda.M. ${ }^{7}$ Quite contrast to our findings, studies in South Carolina, ${ }^{7}{ }^{38} \mathrm{USA}^{38}$ and in Japan suggest dreadful diseases followed by problems of economic distress to be the two most common causes of suicide. Dreadful diseases contributed much less towards the causes of suicide in the present study.

$74.4 \%$ of the total victims in the present study used chemicals for terminating their lives and only $26.8 \%$ of the study group used physical methods for committing FDSH, which is in accordance with the various study done in India and worldwide by Arun 1, 2, 3, B.D Gupta 5, Sachidananda.M ${ }^{7}$, and B.R. Sharma ${ }^{24}$. But in contrast to our study some studies done in India and abroad have shown that the physical methods are most commonly employed method for Fatal deliberate self harm (FDSH). ${ }^{9}, 11,18,52$, 53,75 . 
Amongst those who opted for physical methods, hanging was the most common (15.6\%) followed by burns $(7.1 \%)$. This is in accordance with the findings observed by Arun, ${ }^{1}$ Sachidananda.M, ${ }^{7}$ Danielle. ${ }^{11}$ However, in another study, in Kildare, Ireland, ${ }^{1}$ hanging was the commonest method employed and in South Carolina, ${ }^{102}$ suicide by gunshot was commonly noted in children under the age of 18 years. Hanging is universally available and it is the most common method of suicide globally. ${ }^{1,2,3 \text {, }}$ $5,6,7,8,9,11,20,52,53,102$. In many places, the ready access to firearms makes them potentially dangerous, especially among male adolescents and young adults. ${ }^{18,75}$ Death by firearm was the leading method of suicide in a study done in USA, ${ }^{18,} 38$ accounting for $67.5 \%$ of all deaths. Regional and state-level analysis (1988-1997) of the United States demonstrated a "robust association" between the rates of household firearm ownership and suicide. ${ }^{41}$ Domestic gas has been reported in some studies as a frequently used suicide method. ${ }^{1,5,52,53,102 .}$

Among the poisoning cases, organophosphorus poisoning $(51 \%)$ was the most commonly used method for suicide, which is in contrast to the findings observed in England and Wales, ${ }^{65}$ wherein vehicle exhaust gas has been commonly used and carbon monoxide poisoning was common in Japan. ${ }^{7,9}$ Finding similar to our study have also been observed in India and in other countries by Arun ${ }^{1,2,3}$, Sachidananda.M ${ }^{7}$ and Keith Hawton. ${ }^{38}$ Miscellaneous poisons included Paraquat, Kerosene, Phosphorus, Chlorpromazine, Glyphosate and Cyanide constituting (4\%) of the total cases. People in this region have easy accessibility to organophosphorous insecticides since these are commonly used for agriculture. So whenever there is a tendency to commit suicide, these means are readily available. ${ }^{1,2,3,5,7,8,20,102 .}$

\section{CONCLUSION}

- The incidence of Fatal Deliberate Self Harm (FDSH) was more in the age group of 21-30 years $(35.06 \%)$ and lowest in the age group of less than $10 \mathrm{yrs}(0.45 \%)$.

- Males outnumbered females in our study $(66.5 \%)$. The male female ratio was $2: 1$.

- Majority of the suicide victims were married $(57.3 \%)$.
- Majority of the victims of Fatal Deliberate Self Harm (FDSH) belonged to the Hindu religion $(86.95 \%)$.

- $75 \%$ of the decedents of Fatal Deliberate Self Harm (FDSH) didn't have any history of illness.

- $25 \%$ of the victims of Fatal Deliberate Self Harm (FDSH) had a history of Physical illness and mental illness ranging from hypertension, diabetes, carcinoma to schizophrenia and depression.

- The most favored season for Fatal Deliberate Self Harm (FDSH) was summer, constituting $36.1 \%$ of the total cases analysed.

- Despair with life along with financial constraints $(79.0 \%)$ was the most common motive for the victims of Fatal Deliberate Self Harm (FDSH).

- The most common method used for Fatal Deliberate Self Harm (FDSH) was chemical method constituting $74.2 \%$ of the total cases.

- The most common physical method adopted was hanging constituting $15.6 \%$ of the total number of cases.

- The most common poison consumed was Organ phosphorus insecticide (51\%).

The finding of our study is in accordance with various workers not only in India but studies done worldwide. $1,2,3,5,7,8,9,10,11$ 


\section{REFERENCES}

1. Arun M, Palimar V, Menezes RG, Babu YPR, Bhagavath P. Autopsy study of fatal deliberate self harm. Med Sci Law 2007; 47; 1: 69-73.

2. Arun M, Yoganarasimha K, Palimar V, Kar N and Mohanty MK. Para suicide: an approach to the profile of victims. J Ind Acad Forensic Med 2004; 26 (2): 58-61

3. Arun M, Yoganarasimha K, Kar N, Mohanty MK. The magnitude of the problem. J Ind Acad Forensic Med 2005; 27(4): 243-245.

4. Arun M, Palimar V, Kumar GNP, Menezes RG. Unusual methods of suicide: complexities in investigation. Med Sci Law 2010; 50:149-153.

5. Gupta BD, Singh OG. A Unique trend of murder-suicide in the Jamnagar region of Gujarat. J Forensic Leg Med 2008; 15: 250-255.

6. National crime records bureau. Accidental deaths and suicides in India: ADSI 2010. Available from http://ncrb.gov.in/accdeaths.htm \{accessed on 2012 Oct 9\}.

7. Mohanty S, Sahu G, Mohanty MK, Patnaik M. Suicide in India -A four year retrospective study: J Forensic Leg Med 2007; 14: 185-189.

8. Behera A, Balabantray JK, Nayak SR. Review of Suicidal cases, A Retrospective study. J Ind Acad Forensic Med 2005; 27 (2): 100-102.

9. Pridmore S. Download of Psychiatry, Suicide: a broad view Chapter 31. April, 2011.

10. History of suicide. Source: http://en.wikipedia.org/w/index.php?oldid=480746342. \{accessed on 2012 March $23^{\text {rd }}$.

11. Shaw D, Fernandes JR, Rao C. Suicide in Children and Adolescents. A 10 - Year Retrospective Review. Am J Forensic Med Pathol 2005; 26: 309-315.

12. Beautrais A. Suicides and serious suicide attempts: two populations or one? Psychol Med 2001; 31: 837-845.

13. Cavanagh J, Carson A, Sharpe M, Lawrie $S$. Psychological autopsy studies of suicide: a systematic review. Psychol Med 2003; 33: 395-405.

14. Haukka J, Suominen K, Partonen T, Lönnqvist J. Determinants and outcomes of serious attempted suicide: a nationwide study in Finland, 1996-2003. Am J Epidemiol 2008; 167: 1155-1163.

15. Suominen K, Isometsä E, Suokas J, Haukka J, Achte 1, Lönnqvist J.

Completed suicide after a suicide attempt: a 37-year follow-up study. Am J Psychiatry 2004; 161(3):562563.

16. Suominen K. Attempted suicide in Helsinki: mental disorders and treatment received. Publications of the National Public health Institute NPHI A 24/1998. Hakapaino Oy, Helsinki.

17. DeJong T, James C, Overholser J, Stockmeier C. Apples to oranges? A direct comparison between suicide attempters and suicide completers. J Affect Disord 2010; 124(1-2):90-97.

18. Shields LBE, Hunsaker DM, Hunsaker JC. Suicide: A Ten- Year Retrospective Review of Kentucky Medical Examiner Cases. J Forensic Sci 2005; 50, No. 3: 1-5.

19. Epidemiology of suicide. Source: http://en.wikipedia.org/w/index.php?oldid=498002071 \{Accessed on $31^{\text {st }}$ July 2012$\}$.

20. Reddy MS. Suicide Incidence and epidemiology. Ind $\mathbf{J}$ Psychol Med 2010; 32(7): 77-82.

21. World Health Organization (2002). World report on violence and health. WHO, Geneva
22. Alaraisanen A. Risk Factors and pathways leading to suicide with special focus on Schizophrenia. The Northern Finland 1966 Birth cohort study. Faculty of Medicine, Institute of Clinical Medicine, Department of Psychiatry, Institute of health sciences, University of Oulu.

23. Arun M. A Comparative analysis of suicide and par suicide. M.D Thesis, Department of Forensic medicine, July 2002; MAHE.

24. Sharma BR, Gupta M, Sharma AK et al. Suicides in Northern India: Comparison of trends and review of literature. J Forensic Leg Med 2007; 14: 318-326.

25. Ranchhoddas R, Thakore KD. The Indian Penal Code. $33^{\text {rd }}$ edition. Wadhwa and company Nagpur. Reprint 2006. $568-589$.

26. Ranchhoddas R, Thakore KD. The Code of Criminal Procedure. $17^{\text {th }}$ edition. Wadhwa and company Nagpur. Reprint 2006. 272 - 275.

27. Ranchhoddas R, Thakore KD. The Iaw of Evidence. $24^{\text {th }}$ edition. Wadhwa and company Nagpur. Reprint 2006. $560-563$

28. Suicide legislation. Source: http://en.wikipedia.org/ w/index.php?oldid=480406002. $\left\{\right.$ Accessed on $23^{\text {rd }}$ March 2012\}.

29. The Union of India v. P.Rathinam. All India reporter (AIR) - Supreme Court cases (SCC) 1994; (3): 394

30. State of Andhra Pradesh V Chenna Jagadeeswar. Criminal law journal of India (Cr. LJ) 1988; 549

31. Deshpande VS. "To be or not to be". Supreme Court cases (SCC) 1984; 3: 10 - 15 quoted in P. Rathinam v Union of India (1994)

32. State of Maharashtra v. Maruti Sripati Dubal. Criminal law journal of India (Cr. LJ) 1996; 4457(SC).

33. State of Tamilnadu v Kavita. Criminal law journal of India (Cr. LJ) 1998; 3624.

34. Union of India and ors v. C.A. Thomas Master and etc. Criminal law journal of India (Cr. LJ) 2000; 743.

35. Saha A.N. Right to die- A fundamental right. Criminal law journal of India (Cr. LJ) 1987; 70.

36. State of Punjab v Gian Kaur. All India reporter (AIR) Supreme Court (SC) 1994; 1844.

37. Whether Right To Life Include Right To Die. Source : http://www.legalservicesindia.com/article/print. php?art id $=492$ Author: Manali Singhal. Published on: January 07, 2011. \{accessed on $23^{\text {rd }}$ July 2012 .

38. Mann JJ. Neurobiology of suicidal behaviour. Nat Rev Neurosci 2003; 4(10): 819-828.

39. Gottesman II, Gould TD. The endophenotype concept in psychiatry: etymology and strategic intentions. Am J Psychiatry 2003; 160: 636-645

40. Ivleva EI, Morris DW, Moates AF, Suppes T, Thaker GK, Tamminga CA. Genetics and intermediate phenotypes of the schizophrenia-bipolar disorder boundary. Neurosci Biobehav Rev. 2010; 34(6): 897921.

41. Isohanni I, Järvelin MR, Nieminen $\mathrm{P}$, et al. School performance as a predictor of psychiatric hospitalization in adult life. A 28-year follow-up in the Northern Finland 1966 Birth Cohort. Psychol Med 1998; 28: 967974.

42. McGirr A, Alda M, Séguin M, Cabot S, Lesage A, Turecki G. Familial aggregation of suicide explained by cluster B traits: a three-group family study of suicide controlling for major depressive disorder. Am J Psychiatry 2009; 166: 1124-1134.

43. Mann JJ. In search of endophenotypes for suicidal behaviour. Am J Psychiatry 2009; 166: 1087-108 
44. Pirkola S. Alcohol and other substance misuse in suicide. Publications of the National Public Health Institute NPHI A 14/1999. University press, Helsinki.

45. Henriksson M. Mental disorders in suicide: a comorbidity approach. Publications of the National Public Health Institute NPHI A. Hakapaino Oy, Helsinki 1996.

46. Lönnqvist JK, Henriksson MM, Isometsä ET, et al. Mental disorders and suicide prevention. Psychiatry Clin Neurosci 49 Suppler 1 1995; S111-116.

47. Mann JJ, Apter A, Bertolote J, et al. Suicide prevention strategies: a systematic review. JAMA 2005; 294(16): 2064-2074.

48. Henriksson $\mathrm{M}$, Aro $\mathrm{H}$, Marttunen $\mathrm{M}$, et al. Mental disorders and comorbidity in suicide. Am J Psychiatry 1993; 150: 935-940.

49. Cavanagh J, Carson A, Sharpe M, Lawrie S. Psychological autopsy studies of suicide: a systematic review. Psychol Med 2003; 33: 395-405.

50. Brown G. A Review of Suicide Assessment Measures for Intervention Research with Adults and Older Adults. http://www.suicidology.org/c/document_library/get_file? FolderId=235\&name=DLFE-113.pdf 2002; (access 2.5.2010).

51. Lahti RA, Penttilä A. The validity of death certificates: routine validation of death certification and its effects on mortality statistics. Forensic Sci Int 2001; 115(1-2):1532.

52. Brent $\mathrm{D}$, Bridge J. Firearms availability and suicide. Am Behav Sci 2003; 46(9); 1192-1210.

53. Öhberg A, Lönnqvist J, Sarna S, Vuori E, Penttilä A. Trends and availability of suicide methods in Finland. Proposals for restrictive measures. Br J Psychiatry 1995; 166(1):35-43.

54. Lalwani S, Sharma GASK, Kabra SK, Girdhar S, Dogra TD. Suicide among Children and adolescent in south Delhi (1991-2000). Ind J Pediatr 2004; 71 (8): 701-703.

55. Agerbo E, Nordentoft $M$, Mortensen $P$. Familial, psychiatric, and socioeconomic risk factors for suicide in young people: nested case-control study. BMJ 2002; 325: 74-80.

56. Coryell W, Young EA. Clinical predictors of suicide in primary major depressive disorder. J Clin Psychiatry 2005; 66: 412-417.

57. Goodwin FK, Jamison KR. Manic-depressive illness: bipolar disorders and recurrent depression (2nd edn.), 2007; Oxford University Press, New York.

58. Palmer BA, Pankratz VS, Bostwick JM. The lifetime risk for suicide in schizophrenia. Arch Gen Psychiatry 2005; 62: 247-253.

59. Fernando R, Hewagama M, Priyangika WDD, Range S, Karunaratne S. Study of suicides reported to the Coroner in Colombo, Srilanka. Med Sci Law 2010; 50: 25-28.

60. Phillips MR, Yang G, Zhang Y, Wang L, Ji H, Zhou M. Risk factors for suicide in China: a national case-control psychological autopsy study. Lancet 2002; 360(9347): 1728-1736.

61. Versace M, Loibl LM. Consistency of immigrant and country-of-birth suicide rates: a meta-analysis. Acta Psychiatr Scand 2008; 118: 259-271.

62. Platt S, Hawton K. Suicidal behaviour and the labour market. In: K Hawton and K Van Heeringen, Editors, The international handbook of suicide and attempted suicide, Wiley, Chichester 2000; 303-378.

63. Blakely TA, Collings SCD, Atkinson J. Unemployment and suicide: evidence for a causal association? J Epidemiol Community Health 2003; 57: 594-600.

64. Lindeman S, Läärä E, Hirvonen J, Lönnqvist J. Suicide mortality among medical doctors in Finland: are females more prone to suicide than their male colleagues? Psychol Med 1997; 27(5): 1219-1222
65. Kelly S, Bunting J. Trends in suicide in England and Wales, 1982-96, Popul Trends 1998; 92: 29-41.

66. Qin P, Agerbo E, Mortensen P. Suicide risk in relation to socioeconomic, demographic, psychiatric, and familial factors: a national register-based study of all suicides in Denmark, 1981-1997. Am J Psychiatr 2003; 160: 765772.

67. Riordan D, Selvaraj S, Stark C, Gilbert J. Perinatal circumstances and risk of offspring suicide. Birth cohort study. Br J Psychiatry 2006; 189: 502-507.

68. Silverton L, Mednick S, Holst C, John R. High social class and suicide in persons at risk for schizophrenia. Acta Psychiatr Scand 2008; 117: 192-197.

69. Bondy B. Buettner A, Zill P. Genetics of suicide. Mol Psychiatry2006; 11: 336-351.

70. Li D, He L. Further clarification of the contribution of the tryptophan hydroxylase (TPH) gene to suicidal behaviour using systematic allelic and genotypic metaanalyses. Hum Genet 2006; 119: 233-240.

71. Pezawas L, Meyer-Lindenberg A, Drabant EM, et al. 5 HTTLPR polymorphism impacts human cingulateamygdala interactions: A genetic susceptibility mechanism for depression. Nat Neurosci 2005; 8: 82834.

72. Bayle F, Leroy S, Gourion D et al. 5HTTLPR polymorphism in schizophrenic patients: further support for association with violent suicide attempts. Am J Med Genet B Neuropsychiatr Genet 2003; 119: 13-17.

73. De Luca V, Tharmalingam S, Müller D, Wong G, de Bartolomeis A, Kennedy JL. Gene-gene interaction between MAOA and COMT in suicidal behavior: Analysis in schizophrenia. Brain Res 2006; 1097: 26-30.

74. Yanagi M, Shirakawa O, Kitamura N, Okamura K, Sakurai K, Nishiguchi N. Association of 14-3-3 epsilon gene haplotype with completed suicide in Japanese. J Hum Genet 2005; 50: 210-216.

75. Goren S, Gurkan F, Tirasci Y, Ozen S. Suicide in children and adolescent at a province in Turkey. Am J Forensic Med Pathology 2003; 24: 214-217.

76. Sauvola A, Räsänen $\mathrm{P}$, Joukamaa $\mathrm{M}$, Jokelainen J, Järvelin M-R, Isohanni M. Mortality of young adults in relation to single-parent family background: A prospective study of the Northern Finland 1966 Birth Cohort. Eur J Publ Health 2001; 11: 284-286.

77. Evans J, Heron J, Francomb H, Oke S, Golding J. On behalf of the Avon Longitudinal Study of Parents and Children Study Team (2001). Cohort study of depressed mood during pregnancy and after childbirth. BMJ 2001; 323: 257-260.

78. Mäki P, Riekki T, Miettunen J et al. Schizophrenia in the offspring of antenatally depressed mothers in the Northern Finland 1966 Birth Cohort - relationship to family history of psychosis. Am J Psychiatry 2010; 167 : 160-167.

79. Brennan P, Grekin E, Mortensen E, Mednick S. Relationship of maternal smoking during pregnancy with criminal arrest and hospitalization for substance abuse in male and female adult offspring. Am J Psychiatry 2002; 159: 48-54.

80. Myhrman A, Rantakallio P, Isohanni M, Jones P, Partanen U. Unwantedness of a pregnancy and schizophrenia in the child. Br J Psychiatry 1996; 169: 637-640.

81. Miller M, Hemenway D, Rimm E. Cigarettes and suicide: a prospective study of 50,000 men. Am J Public Health 2000; 90: 768-773.

82. Breslau N, Schultz LR, Johnson EO, Peterson EL, Davis GC. Smoking and the risk of suicidal behavior: a prospective study of a community sample. Arch Gen Psychiatry 2005; 62: 328-334. 
83. Tanskanen A, Viinamäki H, Hintikka J, KoivumaaHonkanen HT, Lehtonen J. Smoking and suicidality among psychiatric patients. Am J Psychiatry 1998; 155: 129-130.

84. Schneider B, Schnabel A, Weber B, Frölich L, Maurer K, Wetterling T. Nicotine use in suicides: a case-control study. Eur Psychiatry 2005; 20(2): 129-136.

85. Moriya, Hashimoto Y. Do smokers who commit suicide have high blood levels of nicotine. Am J Psychiatry 2005; 162: 816-817.

86. Evans E, Hawton K, Rodham K. Factors associated with suicidal phenomena in adolescents: A systematic review of population-based studies. Clin Psychol Rev 2004; 24 : 957-979.

87. Hemmingsson T, Kriebel D. Smoking at age 18-20 and suicide during 26 years of follow-up - how can the association be explained. Int $\mathrm{J}$ Epidemiol 2003; 32: 1000-1004.

88. Gunnell D, Magnusson PKE, Rasmussen F. Low intelligence test scores in 18 year old men and risk of suicide: cohort study. BMJ 2005; 330: 167-171.

89. Hawton K, Sutton L, Haw C, Sinclair J, Deeks J. Schizophrenia and suicide: systematic review of risk factors. Br J Psychiatry 2005; 187: 9-20.

90. Farberow NL, Shneidman ES, Neuringer C. Case history and hospitalization factors in suicides of neuropsychiatric hospital patients. J Nerv Ment Dis 1966; 142: 32-44.

91. Sletten IW, Brown ML, Evenson RC, Altman H. Suicide in mental hospital patients. Dis Nerv Syst 1972; 33: 328-334.

92. Dikshit PC; Asphyxial Deaths, in: Textbook of Forensic Medicine and Toxicology; 1st Edition; Peepee Publishers New Delhi; 2010: 286-317.

93. Mant AK; Mechanical Asphyxia, in: Taylors Principle \& Practice of Medical Jurisprudence; $13^{\text {th }}$ edition; B. I Churchill Livingstone, New Delhi; 1984; 313-315.

94. Kumar GP, Kanthaswamy V. Survival in hanging; J Forensic Med Pathol ; 14(1); 1993; 80-8.

95. Knight B; Self- inflicted injury, in: Bernard Knight Forensic pathology; $111^{\text {rd }}$ Edition; Arnold publishers, London; 2004; 235.

96. Vij K; Asphyxial deaths, in : Text book of forensic medicine and toxicology- Principles \& Practice; Fifth edition; B.I Churchill Livingstone Pvt Ltd, New Delhi; 2011.

97. Subramanyam BV; Deaths from Asphyxia, in: Modi's Medical Jurisprudence and Toxicology; 23 $3^{\text {rd }}$ edition; Butterworth's Wadhwa, Nagpur; 2009; 565 - 569

98. Kumar V. Burnt Wives - A study of suicides. Burns 2003; 29: 31-35

99. Mukherjee JB; Violent Asphyxial Deaths, in: Forensic Medicine \& Toxicology; $2^{\text {nd }}$ edition; Volume $1 ; 1994$; Arnold Associates, New Delhi; 457.

100.Parikh CK; Medicolegal aspects of death investigation, in: Parikh's Textbook of Medical Jurisprudence, Forensic Medicine \& Toxicology for Classrooms and Courtrooms; $6^{\text {th }}$ Edition; CBS Publishers \& distributors, New Delhi; 200.
101.Dimaio DJ, Vincent JM, Dimaio VJM; Drowning, in: Forensic Pathology; Elsevier Science Publishing Co. Inc. New York; 2001; 399.

102.Suicide methods. Source: http://en.wikipedia. org/w/index.php?oldid $=499004707$ accessed on $25^{\text {th }}$ September 2012\}

103.Reddy KSN; Regional Injuries, in: The Essentials of Forensic Medicine \& Toxicology; $31^{\text {st }}$ edition; K Suguna Devi, Hyderabad; 2012; 238.

104.Guharaj PV; Medico legal aspects of wounds, in: Forensic Medicine; $11^{\text {nd }}$ edition; Orient Longman Ltd, Hyderabad; 2003; 156-157.

105.Spitz WU, Fisher RS; Injury by Gunfire, in: Medico legal Investigation of death - Guidelines for the application of pathology to crime investigation; II edition; Charles C Thomas, Springfield IIinois. USA; 1980; 255-257.

106.Tedeschi CG, Eckert WG, Tedeschi LG; Homicidal \& Suicidal deaths, in : Forensic Medicine - A study in trauma \& Environmental Hazards; Volume II; WB Saunders Company, London;1977; 1004-1008.

107.Pillay VV; Irritant Poisons, Modern Medical Toxicology; $3^{\text {rd }}$ Edition; Jaypee Brothers Medical Publishers Ltd. New Delhi; 1999; 61.

108.Polson CJ, Gee DJ, Knight B; Injuries: General features, in: The Essential of Forensic Medicine; $4^{\text {th }}$ edition; Permagon Press, Oxford New York; 1985; 138.

109.Adelson L; The pathology of homicide; I edition; Springfield; Charles C Thomas; 1947; 68.

110.Gajalakshmi V, Peto R. Suicides rates in rural Tamil nadu, South India: Verbal autopsy of 39,000 deaths in 1997-98. Int J of Epidemiol 2007; 36: 203-207.

Source of funding: - None

Conflict of interest: - None 